\title{
NEOLOGISMUL ÎN „MUZA DE LA BURDUJĂNI”
}

\section{Denisa-Maria TOUT ${ }^{*}$}

\section{The Neologisms in Burdujăni’s Muse}

Abstract: The new, the foreign and the unknown needs to be explained. It is like a magnet to the human nature which is eager and also opened to explore the unknown.

The issue of the neologisms entering into the Romanian language is presented in Costache Negruzzi's work entitled Burdujani's Muse, where the author encompasses all his linguistic, literary and social criticism in the figure of Caliopi Busuioc, an old lady who creates poems.

As for the contact with the neologisms, one of its profiles represent the unknown, and the interaction with this unknown being means the understanding of the foreign language.

Another contact with the neologism is made through the motif of the ritual. The feminine character represents a real motif of this ritual when she suddenly starts speaking Italian as if she knew the language.

However, the author puts a heavy accent on a more pregnant matter: the alienation in language and in literature.

Keywords: neologism, foreign, terminology, borrowed words, linguistic mania

Noul, străinul, necunoscutul, se cere a fi explorat. El devine ca un magnet pentru natura umană care se arată dornică şi totodată deschisă la cunoaşterea, captarea şi asimilarea străinului. Persoana, din dorinţa de a poseda cât mai multă înţelepciune, alege ori se mulţumeşte cu lucruri sau aspecte de suprafaţă, artificiale, adică firimituri din autentic şi din original.

De pildă, este vorba de pătrunderea neologismului în spaţiul românesc. Acest fenomen lingvistic aduce cu sine atât o îmbogăţire a lexicului şi, cunoaştem faptul că masa vocabularului aşteaptă cu braţele deschise orice aspect nou, orice inovaţie ce ţine de sfera limbii, cât şi o poartă ce se deschide spre familiarizarea cu alte spaţii geografice, cu ţările străine. Întâlnim această formă lingvistică încă de la Alecsandri, Caragiale, Negruzzi etc. care, apelând la utilizarea neologismului, semnalează raportul dintre aparenţă şi esenţă. Astfel, întâmplările relatate şi aspectele vizate să nu fie tocmai cele pe care le putem deduce de la prima lectură, de la primul

\footnotetext{
* Asist univ. drd., Universitatea de Medicină și Farmacie „Iuliu Hațieganu”, Cluj-Napoca, str. Victor Babeș 8, Cluj-Napoca 400000 (denisa.tout@gmail.com).
} 
contact vizual, ci să medităm asupra concretului, adevăratului sens pe care scriitori-1 conturează.

Legătura strânsă dintre neologism şi jargon rezultă din dorinţa unei pături sociale de a se detaşa, de a se distinge de restul vorbitorilor prin folosirea unor termeni străini, împrumutaţi, tocmai pentru a-şi evidenţia bogăţia lingvistică, respectiv inteligenţa. Problema este aceea că în astfel de cazuri neologismele sunt „stângace”, sunt lipsite de autenticitate: le lipsesc fie câteva litere, fie sunt eliptice de accent sau sunt folosite în situaţii nepotrivite.

De exemplu, Costache Negruzzi, primul junimist, marchează punctual, concret, problema neologismului, îmbrăţişând aceleaşi idei ca Titu Maiorescu, împotriva formelor goale, a formelor fără fond. De altfel, ,întreaga sa critică lingvistică, literară şi socială a concentrat-o în Muza de la Burdujăni. Muza aceasta e cucoana Caliopi Busuioc, o fată bătrână, care face versuri"'.

În opera menţionată, un actor joacă trei roluri de îndrăgostit (neamţ, italian, grec) al cucoanei Caliopi Busuioc, cu scopul de a o compromite în ochii lui Moş Trohin, pentru a-1 favoriza pe nepotul acestuia, Drăgănescu. În privinţa ultimului, slăbiciunea unchiului e o piedică în vederea realizării planurilor sale de căsătorie. George Călinescu defineşte această triadă ca fiind: „concurenţa îndrăgostiţilor de naţiuni felurite - un vechi truc al teatrului italian".

El mai preciza faptul că ,în stropşirea limbajului Negruzzi pune colori locale şi astfel Cucoana Caliopi, care e o preţioasă, rimează în jargon pumnulean”. Criticul face referire la versurile compuse de Caliopi: „Azi cu o petiţiune/ M-adresăi cătră Amor,/ Şi-l rugăi cu-ncordăciune,/ Să astîmpere - al meu dor./ De-a mea tristă pusăciune, / Te îndură, zeu de foc!/ De nu vrei protestăciune/ Să întind în orice loc"2.

Această Caliopi foloseşte mereu în dialogurile sale neologisme „stângace" pronunţate sau scrise greşit, aspect întâlnit şi la celelalte personaje ale operei: „tauletă”, „ştiinţi”, ,poetă”, ,muzicantă”, înamorat”, „,inconvenante”, „insuficient”, „comprinzi” etc. Caliopi atinge involuntar problema lingvistică a „limbii frumoase” în replica adresată către Stănică: „taci, nătărăule, dacă nu comprinzi limba cea frumoasă...”. Ea nu face aici decât să stâlcească această limbă căreia îi atribuie calificativul „,frumoasă”.

Dacă e să rămânem pe marginea ideii - a unei țări frumoase, merită menţionat şi I. H. Rădulescu care afirma că limba română „umblă dezbrăcată" sau că are numai ,zdrenţe” - având nevoie de haine noi. Aceste haine noi nu sunt nimic altceva decât neologismele. Rolul neologismului, semnificaţia lui este aceea a unei haine ,împestriţate" care se potrivește cu

\footnotetext{
${ }^{1}$ Garabet Ibrăileanu, Spiritul critic în cultura românească. Note şi impresii, Bucureşti, Editura Minerva, 1984, p. 79.

${ }^{2}$ Constantin Negruzzi, Păcatele tinereţelor, Bucureşti, Editura Minerva, 1983, p. 193.
} 
„găteala" Caliopei ce constă în asocierea, combinarea culorilor şi a fibrelor diverse.

Însuşi Teodorini remarcă ,găteala” acesteia: „găteala d-tale nu seamănă a bolnavă, mi se pare că cine nu se simte bine nu trebuie să se strîngă aşa tare". Negarea Caliopei nu face decât să-şi dezvăluie esenţa carei depăşeşte aparenţa şi să se ascundă după masca falsităţii.

Având ca reper termenul ,împestriţat” pe care-1 asociez unei aglomerări de culori şi de fibre diferite, cuvântul trece din sfera planului vestimentar în zona celui caricatural. De pildă, portretul Caliopei, realizat de Drăgănescu, se potrivește perfect, ermetic cu acest aspect, conturându-i modul de viaţă pe planurile cultural şi social - un mod artificial şi fals: „o alcătuire de toate ridiculele trecute, prezente şi viitoare, o fată bătrână şi nebună care-şi închipuieşte că nebuneşte pe toţi bărbaţii, şi socoate că nu-i poţi zice bună dimineaţă fără să-i faci o declaraţie de amor. Când va fi nesuferită, când simtimentală şi cochetă, s-aprinde şi se alintă ca o copilă brudnică, şi deodată o vezi că se aruncă în disertaţii metafizice şi în dispute literare, de n-o mai înţălege nici dracul. Toată dorinţa ei e s-audă vorbind de dânsa", . Această descriere îi relevă de fapt disimularea şi comportamentul labil.

În ceea ce priveşte contactul cu neologismul, unul dintre profilurile acestuia îl reprezintă străinul, iar interacţiunea cu această prezenţă străină presupune şi înţelegerea limbii străine.

De subliniat este faptul că personajul feminin nu recunoaşte apariţia în trei ipostaze a lui Teodorini. De fapt, masca actorului evidenţiează inocenţa, neştiinţa Caliopei ce rămâne captivă spaţiului incognoscibil. Ignoranţa „muzei” reiese din contactul cu străinul, cu cele trei apariţii ale necunoscutului: italianul, grecul şi neamţul.

Garabet Ibrăileanu o numeşte „femeie romanţioasă, care răspunde baronului Flaimuc, falsului pretendent" atunci când acesta îi spune că doreşte o femeie „care să facă la mine poezii no vi der Şiller vi der Ghete”. [...] / „Ghete! Shiller! ce nume inalte ai rostit, baron! Feblele mele talente cum va răspunde la aşteptarea dumitale?".

Acelaşi critic o acuză fiindcă ,strică limba, influenţată de toate maniile lingvistice ale vremii (pusăciune, comprinzi, neînvincibilă, atăşăciune etc.)"4.

Caliopi este văzută şi ca o persoană „modernă” care-i recomandă bătrânului ei amorez: „să te îmbraci după modă. În locul nădragilor acelor roşi, să pui un pantalon elegant, botine de glanţ, un bonjur făcut după jurnal ca toată lumea bine educată”.

\footnotetext{
${ }^{3}$ Ibidem, p. 191.

${ }^{4}$ Garabet Ibrăileanu, Idem, p. 79.
} 
O altă formă de contact cu neologismul este realizat prin intermediul ritualului. Se poate vorbi de un adevărat ritual, în privinţa personajului feminin, în momentul când ea vorbeşte brusc în italiană ca şi cum ar cunoaşte limba , particula: „pieta, Signore, chiedo, [...] Son un povera donzella [...] Sventurata, a! Son io!”.

De fapt, ea nu face nimic altceva decât să răspundă după un model. În acest sens, nu comprehensiunea ocupă poziţia primă, ci însăşi acţiunea. Practic, aici, Caliopi creează limba. Problema acesteia este că ea nu distinge între ipostazele străinului, iar cunoaşterea limbii străine pe care consideră că o deţine sunt simple aparenţe, sunt goluri, sunt spaţii pustii.

Caliopi Busuioc e o femeie ridicolă care are doar pretenţia unei galanterii, a eleganţei, a rafinamentului şi a inteligenţei. De altfel, întreaga piesă conţine nu numai ,ridiculizarea maniei lingvistice, ci şi satirizarea ridicolului. [...] Costache Negruzzi, cum spune singur, a voit să ridiculizeze pe croitorii limbii: a ales o femeie"

Pe tot parcursul piesei se poate observa prezenţa unor termeni de origine latină, franceză şi italiană ce ţin de linia lingvistică romanică. Scopul utilizării acestora de către autor a fost acela de a ironiza, de a lua în râs, de „a-şi bate joc cu mult spirit de mania latinistă şi franţuzistă"6.

De exemplu, într-una dintre scrisori, mai exact în Scrisoarea a XXV-a (Omul de ţară), autorul redă spusele unui ţăran: ,-, Pre unul am să-1 dau în şcoală la Iaşi, ca să înveţe nemţeşte, franţuzeşte şi latineş̧e. - Dar româneşte nu? - Ba şi româneşte; da, vezi d-ta, că dacă n-a învăţa franţuzeşte şi latineşte nu înţelege româneasca de astăzi. Acum trebuie să ştim multe limbi, ca să înţelegem pre a noastră". Răspunsul lui Negruzzi este ferm, iar soluţia: „,- Iată ce. Să-i daţi la dascălul din sat să-i înveţe limba lor ca să poată ceti cărţile cele bune care-i învaţă cum să cinstească pre Dumnezeu, pre părinţi şi pre mai marii lor"7.

Referitor la împrumuturile din limba latină şi din limbile romanice, criticul Liviu Leonte remarca: „Negruzzi are cunoştinţe de limbă, unele depăşite astăzi, reuşind totuşi să se închege într-o unitate şi să convingă prin logică, nu numai prin vervă. La prima sa apariţie publicistică şi editorială, prefaţa la Triizeci ani sau viaţa unui jucători de cărţi, Negruzzi explică cuvintile streine folosite în traducere ca împrumuturi din latină şi din limbile romanice" ${ }^{\text {. }}$.

De altfel, există o legătură strânsă între cele trei ipostaze ale lui Teodorini şi cunoaşterea limbii străine de către Caliopi, respectiv folosirea neologismelor. Prin urmare, dacă aceasta nu recunoaşte românul, atunci nu cunoaşte nimic despre alteritate, despre imaginea celuilalt, despre străin.

\footnotetext{
${ }^{5}$ Ibidem, pp. 80-81.

${ }^{6}$ Ibidem, p. 79.

${ }^{7}$ Constantin Negruzzi, Idem, pp. 311-313.

${ }^{8}$ Liviu Leonte, Constantin Negruzzi, Bucureşti, Editura Minerva, 1980, p. 68.
} 
Pentru ea totul devine o „bizarerie”. Cunoaşterea limbi române devine chiar o problemă existenţială ce este ridicată la toate nivelurile sociale.

În ceea ce priveşte înţelegerea limbii străine, Caliopi întâmpină dificultăţi, pe motiv că ea înţelege doar ce-i convine, ce i se potriveşte, ce ar dori să ştie sau să creadă.

Scopul pentru care Negruzzi a creat această „farsă” îl dezvăluie într-o Notă de la sfârşitul piesei: ,noi am fost zis - nu ne mai aducem aminte unde - că sânt mulţi care schingiuiesc şi sfâşie frumoasa noastră limbă, şi în loc de creatori se fac croitori răi. Asta ne-a îndemnat a compune această mică comedie, crezând că facem un bine arătând ridicolul unor asemine neologişti",

Garabet Ibrăileanu face o precizare în acest sens: „nu-i vorbă, farsa aceasta e peste măsură de slabă. Chiar alegerea locului, Burbujenii, e o copilărie, căci la Burdujeni nu putea exista o asemenea «muză». [...] Dacă-i vorba de ridiculizat, de caricaturizat, apoi ei vor pune pe Caliopi Busuioc la Burdujeni","

În privinţa neologismelor la Negruzzi, Liviu Leonte sublinia: „faţă de neologisme, are o atitudine mai reţinută [...] Alături de ideea adaptării, foarte judicioasă, întâlnim propunerea de a traduce cuvintele străine prin cuvintele şi mijloacele limbii române" ${ }^{\text {"11 }}$.

Pe lângă această necesitate a traducerii, „neologismelor le sânt preferate cuvintele din fondul vechi al limbii"12. În acest sens, stă afirmaţia lui Negruzzi: „de ce să zicem delicios, ruină, torent, sacru etc.; în vreme ce avem chiar zicerile noastre: desfătător, năruire, şioi [şiroi], sfinţit" ".

Alternanţa neologismului de origine franceză cu termenul de origine neogreacă „,ne face să credem că Negruzzi a avut în faţă textul original şi că grecismele care dau o savoare orientală replicilor, le-a introdus din vorbirea proprie" 14 .

Astfel, criticul Leonte consideră: „,cucoana Caliopi din Muza de la Burdujăni, alături de franţuzisme şi pumnisme, mai scapă câte un servirarisariseşte sau un menajarisit" ${ }^{\prime 15}$.

În concluzie, Costache Negruzzi pune accentul mult mai grav şi mai pregnant, subliniind importanţa majoră a problemei ,înstrăinării” în limbă şi în literatură. Nu putem spune că scriitorul este împotriva împrumuturilor, a neologismelor, pe motiv că el apreciează lumile civilizate: „se-mbracă

\footnotetext{
${ }^{9}$ Constantin Negruzzi, Idem, p. 220.

${ }^{10}$ Garabet Ibrăileanu, Idem, p. 80.

${ }^{11}$ Liviu Leonte, Idem, p. 68.

12 Ibidem, p. 69.

${ }^{13}$ Constantin Negruzzi, Opere complete, vol.1, Proză, ediţia a II-a, Bucureşti, Minerva, 1916, pp. 301-302.

${ }^{14}$ Liviu Leonte, Idem, pp. 82-83.

15 Ibidem, p. 74.
} 
nemţeşte, gustă teatrul şi opera franceză şi italiană, ceteşte pe Victor Hugo, călătoreşte pe la staţiile balneare din Europa, e duelgiu, e, în sfârşit, european. Dar e împotriva civilizaţiei pentru masa cea mare a poporului român"16.

\section{Bibliografia}

a) Opera:

1. NegruZZI, Constantin (1916) Opere complete, vol.1, Proză, ediţia a II-a, București, Editura Minerva.

2. NegruZZI, Constantin (1983) Păcatele tinerețelor, Bucureşti, Editura Minerva.

b) Referinţe critice:

3. CĂLINESCU, George (1983) Istoria literaturii române, Bucureşti, Editura Minerva.

4. IBRĂILEANU, Garabet (1984) Spiritul critic în cultura românească. Note şi impresii, Bucureşti, Editura Minerva.

5. LeOnTE, Liviu (1980) Constantin Negruzzi, București, Editura Minerva.

\footnotetext{
${ }^{16}$ Garabet Ibrăileanu, Idem, p. 76.
} 